\author{
JoLANTA JóźWIAK \\ Uniwersytet Kazimierza Wielkiego (Bydgoszcz, Polska)
}

\title{
Inwencja językowa dzieci (na materiale języka rosyjskiego)
}

Wśród ogromnej liczby pozycji językoznawczych niezbyt często można spotkać opracowania z zakresu badań nad szczególnymi przejawami kreatywności językowej dzieci. Publikacje związane są z obszarem nauk psychologicznych oraz pedagogicznych i dotyczą badań nad kształtowaniem się mowy dziecka na różnych etapach jego rozwoju, a więc kwestii przyswajania języka naturalnego, oraz badań związanych z rozwojem dziecka, możliwymi zaburzeniami rozwojowymi itd. Odzwierciedlenie w literaturze znajduje także problematyka akwizycji języków obcych w trakcie nauczania na etapie przedszkolnym czy wczesnoszkolnym ${ }^{1}$. Twórczość językowa najmłodszych użytkowników języka, wynikająca z kreatywności młodych umysłów, znacznie rzadziej niż inne fragmenty rzeczywistości językowej znajduje się w polu zainteresowania lingwistów, być może $\mathrm{z}$ racji pewnej nieprzewidywalności dziecięcych kreacji językowych, które wydają się nie poddawać konwencjom językowym.

Dzieci stopniowo poszerzają swoją wiedzę na temat reguł oraz funkcjonowania systemu języka ojczystego, stosując coraz to bardziej skomplikowane sposoby tworzenia słów i ucząc się zastosowania poznawanych stopniowo jednostek w określonym kontekście i w nowych sytuacjach.

Wiele miejsca poświęca się badaniom akwizycji języka naturalnego, psychologicznym podstawom kształtowania się mowy ludzkiej. Na szeroką skalę prowadzone są również badania związane z akwizycją języków obcych i podniesieniem efektywności tego procesu. W niniejszym artykule poruszono specyficzną kwestię kreatywności językowej dzieci, ale przywołajmy w tym miejscu chociaż kilka znanych propozycji o wspomnianej ogólniejszej tematyce, ponieważ wszystkich nie sposób tu wymienić, por. np.: E. Dąbrowska, W. Kubiński (red.) (2003), Akwizycja języka w świetle językoznawstwa kognitywnego, Warszawa, Universitas; J. B. Gleason, N. B. Ratner (2005), Psycholingwistyka, Gdańsk, GWP; I. Kurcz (2005), Psychologia języka i komunikacji, seria Wykłady z psychologii, t. 2, Warszawa, Wydawnictwo Naukowe Scholar; J. Piaget J. (2005), Mowa i myślenie dziecka, Warszawa, PWN; R. Schaffer (2005), Psychologia dziecka, Warszawa, PWN; G. W. Shugar, M. Smoczyńska (red.) (1980), Badania nad rozwojem języka dziecka, Warszawa, PWN; a także F. Grucza (red.), (1989), Bilingwizm, bikulturyzm, implikacje glottodydaktyczne, Warszawa, Wydawnictwo UW; F. Grucza, Języki ludzkie a wyrażenia językowe, wiedza a informacja, mózg a umyst ludzki, [w:] F. Grucza, M. Dakowska (red.) (1997), Podejście kognitywne w lingwistyce, translatoryce i glottodydaktyce, Warszawa, Wydawnictwo UW, s. 7-23. 
W procesie przyswajania zasad rządzących systemem językowym pojawiają się oczywiście tak charakterystyczne dla języka dzieci nieprawidłowości, zniekształcenia itd. Można powiedzieć, że dzieci eksperymentują w ramach słowotwórstwa, gramatyki, składni, semantyki. K. Czukowski uważał „nieświadomą twórczość językową" za ,jeden z najbardziej zadziwiających fenomenów dzieciństwa" (Czukowski 2001).

Przedmiotem niniejszych rozważań będą rosyjskie jednostki językowe wyekscerpowane ze Stownika wspótczesnego języka dziecięcego autorstwa W. K. Charczenko. Jest to jedna $\mathrm{z}$ niewielu dostępnych pozycji dotyczących interesującego nas zakresu, wydana w postaci dwutomowego słownika, w której zebrane zostało ponad 3500 przykładów wypowiedzi dzieci w różnym wieku. Trzeba zaznaczyć, iż nie jest to tradycyjne opracowanie leksykograficzne. Niestety pewna część jednostek to raczej zapis wypowiedzi dziecięcych bez komentarza lingwistycznego. Nie stanowią one haseł słownikowych opatrzonych definicją i wyjaśnieniem znaczenia, jest to po prostu użycie kontekstowe, które może stać się materiałem wyjściowym do dalszych badań. Niemniej jednak zebrany materiał skłania do przeprowadzenia analiz języka dziecięcego z różnych perspektyw i jedna z takich propozycji zostanie przedstawiona poniżej.

Przegląd zamieszczonych w słowniku jednostek pozwala podjąć próbę rekonstrukcji niektórych mechanizmów poznawczych, zachodzących w trakcie procesu tworzenia przez dzieci rozmaitych określeń oraz posługiwania się językiem, i w ogólnych zarysach przedstawić pewne tendencje słowotwórcze.

W bardzo bogatych pod względem treści jednostkach języka dziecięcego i ich realizacjach językowych znajduje swoją reprezentację pewien szczególny sposób postrzegania i pojmowania świata, swoisty punkt widzenia na otaczającą rzeczywistość. A zatem w pełni uzasadnione wydaje się wprowadzenie terminu dziecięcy językowy obraz świata (Tuchareli 2001: 6) jako szczególnego sposobu konceptualizacji rzeczywistości, specyficznego odzwierciedlenia fizycznych i psychicznych realiów w języku dzieci.

W niniejszym artykule opisowi i analizie zostaną poddane wybrane jednostki językowe, w procesie formowania których w sposób niekonwencjonalny wykorzystywane są przez dzieci modele słowotwórcze ogólnie stosowane w języku rosyjskim, ze szczególnym uwzględnieniem przykładów odzwierciedlających asocjacyjny charakter motywacji. W omawianych formacjach wykorzystywane są dostępne w języku rosyjskim morfemy słowotwórcze, ale pojawiają się one w innych kombinacjach, należących do sfery potencjalnej (ale nie uzualnej) systemu językowego. Należy odnotować, iż niektóre z prezentowanych w niniejszym artykule jednostek funkcjonują dość powszechnie w języku potocznym, jednak zostały poddane analizie, gdyż autorka słownika zakwalifikowała je jako należące do języka dziecięcego.

Spektrum wszelkiego rodzaju odchyleń od normy językowej w języku dzieci jest bardzo szerokie. Chodzi tu o błędy wynikające z niewiedzy o semantyce po- 
szczególnych wyrazów, z nieznajomości lub niedostatecznego opanowania zasad fonetycznych, ortograficznych, słowotwórczych, gramatycznych (rodzaj, fleksja), relacji składniowych. Zmiany tego rodzaju prowadzą do powstawania form, wywołujących często uśmiech u rodziców i badaczy, ale ich analiza pozwala zrozumieć etapy opanowywania języka ojczystego. Często pozornie proste przypadki, jak na przykład zamiana litery na inną w słowie одеванчик - 'одуванчик', mają skomplikowane podłoże i prowadzą do określonych konsekwencji semantycznych. Modyfikacja nie wynika zapewne tylko z nieznajomości prawidłowej wersji wyrazu, ale również z podobieństwa brzmieniowego rdzenia do praktycznie codziennie słyszanego i używanego czasownika одеваться, co jest świadectwem procesów mentalnych zachodzących w umyśle dziecka podczas nazywania przedmiotów oraz zjawisk.

Poddane analizie przykłady dziecięcej twórczości językowej należą do sfery słownictwa nieuzualnego. J. A. Ziemskaja rozgranicza dwie klasy słów, należących do danego zakresu: słowa potencjalne i okazjonalne. Słowa potencjalne tworzone są za pomocą najbardziej produktywnych typów, wypełniając puste miejsca paradygmatów słowotwórczych, natomiast okazjonalizmy stanowią jakby przeciwstawienie dla słów uzualnych, naruszają reguły, wykorzystują martwe afiksy, „nie te" podstawy itd. (Ziemskaja 2007: 180).

Omawiane słownictwo dziecięce ma charakter zarówno potencjalny, jak i okazjonalny, chociaż w trochę innej perspektywie. Dzieci wykorzystują nie tyle najbardziej produktywne typy słowotwórcze, ile modele najbardziej znane im na danym etapie rozwoju, stosując jednocześnie nietradycyjne podstawy słowotwórcze i afiksy.

W związku z powyższym w analizowanym materiale można wyróżnić dwie duże grupy wyrazów: zniekształcenia strukturalne o charakterze potencjalnym oraz innowacje językowe o charakterze okazjonalnym.

Do pierwszej grupy należą zniekształcenia, które można traktować jako błędne w odniesieniu do słowotwórczej normy językowej, lecz trzeba jednocześnie zaznaczyć, iż znajdują w nich odzwierciedlenie istniejące reguły tworzenia słów. Ujawniają one także pewne niekonsekwencje i nieregularności w systemie językowym, jakim posługują się dorośli. Przykłady nienormatywnego posługiwania się systemem językowym pozostają w pewnej zależności z tendencją do używania innych niż tradycyjne formantów słowotwórczych. W wypadku prezentowanych poniżej czasowników oraz przymiotników należałoby ten proces powiązać z niewystarczającą wiedzą dotyczącą stosowania abstrakcyjnych reguł gramatycznych. W języku rosyjskim zjawisko to wyraźnie zauważalne jest przy tworzeniu wspomnianych czasowników, por.: выздоровлять - 'выздоравливать' (- Не болей, выздоровляй!); прищеплять - 'прицепить' (Играют на детской площадке: Мам, там надо его прицеплить). Przyczyny powstawania nieprawidłowości podobnego rodzaju w języku dzieci w różnych przedziałach wiekowych, a także ich szczegółowe klasyfikacje są szeroko omówione w literaturze przedmiotu (por. np. Cejtlin 2000), dlatego w tym miejscu problematyka ta została tylko zasygnalizowana. 
Wyraźną trudność sprawiają też dzieciom przymiotniki. Sufiksy, za których pomocą powstają, mają ściśle określony, powtarzalny charakter, ale z punktu widzenia najmłodszych użytkowników języka mogą być stosowane w miarę dowolnie, ponieważ w doświadczeniu językowym brakuje jeszcze wiedzy odnośnie do szczegółowych zasad tworzenia poszczególnych kategorii gramatycznych wyrazów. Dlatego też w użyciu znajdują się poniższe formy, por.: змеяный 'змеиный' (- Там даже большие ребята - рассказывал Ролан - в змеяную яму прыгали!); медвежоночий - 'медвежий' (Это медвежоночьи следы?); медвежоный - 'медвежий' (А Шермухамед и Пафнутий (плюшевые мишки) в медвежоной больнице); курищев - 'куриный' (Играет в повара: мясо дать курицево?), одногорбатый - 'одногорбый' (Рассматривает картинки: Одногорбатый и двухгорбатый верблюд!); телевизорный - 'телевизионный' (- Это будет антенна. - Телевизорная?), a także кудривый - 'кудрявый’; родительный - 'родительский'; собачный - 'собачий' и т.д.

Niekonwencjonalne sufiksy przyłączane są do właściwych podstaw również w nominacjach rzeczownikowych: официантист - 'официант' (Играет: Я офиииантист. Что будете заказывать?), шахматун - 'шахматист' (Играет в шахматы с дедушкой. - Мы шахматуны!) Należy odnotować, że wszystkie formanty odnoszą się do właściwej kategorii - nazw wykonawców czynności.

Dzieci patrzą na świat $\mathrm{z}$ wielkim zainteresowaniem, obserwują zachowania językowe dorosłych i szybko spostrzegają pewne schematy tworzenia słów, posługiwania się cząstkami semantycznymi, pomimo nieznajomości systemu językowego, a często wręcz nieświadomości co do jego istnienia i ścisłej kodyfikacji. W miarę upływu lat dzieci coraz częściej przestają stosować bezkrytycznie zaobserwowane reguły, zaczynają zastanawiać się, czy rzeczywiście można się nimi posługiwać tak, jak w znanych im formacjach, co potwierdza treść niektórych haseł słownikowych, por. утконосица - (А что, если самец - утконос, то самка - утконосица?).

Szczególną grupę wśród nominacji rzeczownikowych stanowią osobliwe zdrobnienia lub zgrubienia. Obecność deminutywnych lub augmentatywnych formantów w słowach, w których zwykle się nie pojawiają, można uznać za cechę charakterystyczną dziecięcego leksykonu, nawet jeśli weźmiemy pod uwagę fakt, iż sufiksy zdrabniające występują $\mathrm{w}$ języku rosyjskim również w charakterystycznej funkcji wskaźników stylu potocznego, por., господинка - 'маленькая госпожа' (Брат играет с сестрой: Господинка, уйди с дороги!); господиха 'госпожа' (Мама - господиха); броненосик 'маленький броненосец' (Играет со зверюшками: А здесь будет броненосик маленький).

Niekiedy już sama podstawa niesie tego rodzaju znaczenie, por. папанюшка - 'ласк. к папа' (- Ты мой любимый папанюшка!), котененочек - 'ласк. к котеночек' (Обнимает маму: Я твой котененочек), albo występuje przy podstawie formant o charakterze przeciwnym, por.: котиха 'кошка' (Дина рассказывает: а мы видели, как через дорогу шла котиха и котенок) (warto 
zwrócić uwagę na wyraźne odzwierciedlenie w zastosowaniu sufiksów opozycji duży - mały²). Warto zwrócić uwagę na wyraz ведьмочка - (Саша говорит, что я с распущенными волосами как ведьмочка. Неправда?), w którego sposobie utworzenia odczuwalna jest rozbieżność negatywnej konotacji podstawy i pozytywnego wartościowania sufiksu zdrabniającego, wskazującego na wielkość podmiotu.

We wczesnych etapach rozwoju otwartość umysłu dziecka, a co za tym idzie - kreatywność, nie są skrępowane sztywnymi regułami, z którymi dzieci spotykają się rozpoczynając edukację w szkole, w rezultacie dzieci dosyć swobodnie „przekładają” obraz świata na jednostki językowe. Młodzi użytkownicy języka intuicyjnie wyczuwają istnienie w języku pewnych prawidłowości, starają się wykorzystać swoją wiedzę, kierując się prostą logiką i postrzeganiem zmysłowym.

W rezultacie takiego podejścia powstają obrazowe jednostki o charakterze okazjonalnym, zaklasyfikowane wcześniej do drugiej obszernej grupy innowacji językowych.

Dzieci często tworzą wyrazy, można powiedzieć, zgodnie z obowiązującymi zasadami, stosując formanty o właściwym znaczeniu, łącząc jednak te znaczące cząstki z niewłaściwymi (ale tylko z punktu widzenia przyjętych norm!) podstawami słowotwórczymi, które bezpośrednio odwołują się na przykład do znanych dzieciom nazw czynności, por.: куриники - 'сигареты' (Папа надоел со своими куриниками. Всё курит и курит); говоритель - 'рассказчик' (- А он говоритель хороший); говорилка - 'рот'; копатка - 'лопатка'. W podobnych sytuacjach nazwa wykonywanej czynności staje się podstawą dla nominacji rzeczownikowej, czyli przedmiot lub osoba charakteryzowane są od strony czynności, por. держалка - 'ручка, рукоятка' (Нашёл ручку от лупы: Это держалка такая?); догонялки - (- А еще во что ты любишь играть? - В догонялки!); слушателька - 'терапевт, пульмонолог, врач, работающий с фонендоскопом, слушающий дыхание' і стрижачка - 'парикмахер' (- Я буду стрижсачкой в парикмахерской работать или слушателькой в больнице).

Podstawą motywacji mogą być również nazwy miejsc lub przedmiotów: телевизионщик - (Кто работает на радио? Кто читает новости, как называется? - Телевизионщик!?); чердачник - 'человек, живущий в мезонине' (- Мы не дачники, мы чердачники!); зонтиковый - 'дождливый' (О погоде. - Завтра опять будет зонтиковая погода?).

Należy odnotować, iż łączenie sufiksów z niestandardowymi podstawami słowotwórczymi właściwie zawsze oparte jest na analogii. Podobnego typu jednostki powstają w oparciu o znane najmłodszym użytkownikom języka wzorce i w ten właśnie sposób powstają struktury analogiczne do istniejących, przy czym dotyczy to zapewne zarówno leksykonu czynnego, jak i biernego.

Analiza konceptualna opozycji semantycznej mały - duży na przykładzie nazw osób ze względu na wiek została szerzej omówiona w: Н. Л. Тухарели, Семантическая оппозиция маленький - большой в детской языковой картине мира; w: В. В. Красных, А. И. Изотов (ред.), Язык. Сознание. Коммуникация, вып. 12, Москва 2002, с. 41-50. 
Według słów J. A. Ziemskiej (Ziemskaja 2007: 182), bez analogii nie powstaje nie tylko ani jedno słowo o charakterze uzualnym, ale również ani jedno o charakterze okazjonalnym, z tym że w wypadku okazjonalizmów analogia funkcjonuje jako konkretny wzorzec, natomiast w słowotwórstwie uzualnym w postaci abstrakcyjnych analogicznych reguł.

Jeśli chodzi o wybór podstawy motywacji, trzeba pamiętać, iż jest to suwerenny wybór dziecka, które stara się nadać nazwę danemu fragmentowi rzeczywistości, a, jak pisał J. Rozwadowski, w trakcie procesu nazywania przedmiotów zawsze podkreślana jest tylko jedna strona, jedna cecha przedmiotu czy zjawiska (Rozwadowski 1960: 22), przy czym w wypadku mowy dziecięcej zawsze jest to cecha, którą dziecko z własnej perspektywy uzna w danej sytuacji za dyferencjującą i dominującą. Zróżnicowanie sposobów słowotwórczych i wybór konkretnych sufiksów będzie natomiast zależał od znajomości i umiejętności posługiwania się konkretnymi wzorcami słowotwórczymi.

W analizowanym materiale występuje również wiele obrazowych nazw czynności. Często tworzone są one od nazw przedmiotów będących podmiotem, obiektem danej czynności, narzędziem działania lub stanem, w jakim znajduje się przedmiot itd., por. ведущить - 'быть ведущим' (- Нет-нет, я не буду ведущить!); гитарить - 'играть на гитаре' (- Папа, дай я погитарю!); грубиянничать 'грубить, вести себя как грубиян' (- Саша грубиянничает со мной!); грязнеть - 'становиться грязным' (- Я руки еле отмыла. - А от чего они грязнеют? Грязнели отчего?); сургучить - 'запечатывать сургучом' (Играет в почту: Я буду сургучить посылки); утюговать - 'утюжить бельё, гладить' (- Я тоже, как мама, буду утюговать); шпиончить - ‘играть в шпионов’ (- Покушаем макароны и будем шпиончить?). Tego rodzaju wyrazy powstają nie tylko za pomocą sufiksacji, ale również na przykład sposobem prefiksalno-sufiksalnym, co wnosi kolejne odcienie znaczeniowe, por.: запластилинить - 'залепить пластилином' (- Что ты эту сторону всю запластилинила?); заприщевать - 'прикреплять прищепками' (Подает матери прищепки: На, заприщевай бельё! - Что делать? - Припещай!); убольшить - 'увеличить в размере' (- Я смотрю, как надо его (воротник) уменьшить. - Нет, его надо убольшить!).

Warto również podkreślić naturalną tendencję do nazywania nowych przedmiotów i zjawisk w oparciu o tzw. formę wewnętrzną, do której językoznawcy wielokrotnie odwołują się w trakcie rozważań na temat zależności między formą a treścią. A. Potiebnia uważał, iż jest to pewien mechanizm językowy, który ujawnia się zawsze, kiedy występuje potrzeba zrozumienia i utrwalenia $\mathrm{w}$ języku nowego zjawiska, tzn. wyrażenia słowem nowej treści (Potiebnia 1976: 300). Forma wewnętrzna może być również rozumiana jako pewna semantyczna i strukturalna relacja morfemów składowych słowa z innym słowem danego języka, a także jako cecha leżąca u podstaw nominacji w procesie formowania nowego znaczenia leksykalnego słowa (Jarcewa 2002: 85). Znajdujące się w analizowanym materiale przykłady złożeń odzwierciedlają skomplikowany mechanizm na- 
zywania nowego zjawiska poprzez odwołanie (chociaż tylko pośrednio) do cech wpływających na tworzenie nowego określenia. Pierwszym z nich jest kreatywne określenie черепахорыборак - 'о крабе' (Впервые увидела краба: Это... черепахорыборак?). W terminologii R. Grzegorczykowej i J. Puzyniny dany twór należałoby uznać za derywat asocjacyjny (onomazjologiczny) (Grzegorczykowa, Puzynina 1979: 21), ponieważ w znaczeniu danej jednostki językowej odczuwalny jest związek asocjacyjny z cechami dominującymi percepcyjnie w momencie nazywania. Równie mocno przemawia do wyobraźni złożenie, które powstało poprzez zamianę jednego członu składowego słowa w oparciu o bezpośrednią perсерсје,, asocjację, por. смашинотворение - 'скопление машин' (- Что это за столпотворение! - Не столпотворение, а смашинотворение).

Kolejną grupę dziecięcych innowacji stanowią jednostki utworzone w wyniku procesu kontaminacji. Kontaminacja określana jest jako sposób połączenia dwóch słów uzualnych, w którego wyniku powstaje trzecie - okazjonalizm, przy czym część jednego słowa zostaje usunięta, tzn. nie wchodzi w skład okazjonalizmu, ale nadal pozostaje w tle, ułatwiając semantyzację obydwu elementów okazjonalizmu (Ziemskaja 2007: 191). Następujące mniej lub bardziej obrazowe jednostki z badanego materiału można zaklasyfikować jako spontaniczne kontaminacje leksykalne: кукух, петушка - (кукушка + петух) (Рассказывает стихотворение, волнуется, перепутал: Петушка и кукух!); покогда - (пока + когда) (Но покогда началась война, он (прадедушка) ушел на войну); свинотит - (свинка + отит) (Играет с куклами в больницу: У нее свинотит!); Чебуратино - (Чебурашка + Буратино) (Это Чебуратино!), а также пажук‘жук' (паук + жук); чуприз - 'сюрприз' (чудо + сюрприз).

Kontaminacje w języku dzieci pojawiają się nie tylko w obrębie oddzielnych słów, ale także wśród połączeń wyrazowych, w tym stałych związków wyrazowych oraz frazeologizmów, które zostały szczegółowo omówione w artykule K. Ratajczyk (por. Ratajczyk 2010).

W innowacjach językowych znajduje odzwierciedlenie aspekt pragmatyczny. Dzieci tworzą nowe słowa w sytuacjach dla nich nowych, kiedy nie znają słów określających nieznane im zjawiska lub sytuacje, które jednak interpretują odwołując się do analogicznych sytuacji, do swojego dotychczasowego doświadczenia. Pragmatyka wiąże się bezpośrednio z użytecznością w danej sytuacji, co możemy zinterpretować w kategoriach reguł konwersacyjnych Grice'a.

Kreatywność wyraźnie wzrasta pod wpływem emocji. Świadczą o tym choćby pojawiające się niejednokrotnie w przytaczanych użyciach kontekstowych wykrzykniki. Z biegiem czasu taka spontaniczna kreatywność podlega kolejnym ograniczeniom, aż praktycznie zanika albo co najwyżej może być świadomie aktywizowana przez dorosłych w określonych sytuacjach. Dzieje się tak zapewne pod wpływem zmiany społecznego wartościowania omówionych jednostek językowych. U dzieci, jeśli nawet podobne zachowania językowe wywołują uśmiech lub spontaniczną reakcję emocjonalną dorosłych, to towarzyszą im pozytywne 
asocjacje lub w najgorszym wypadku pobłażanie z racji wieku użytkowników języka. W dorosłym życiu natomiast, jeśli tego rodzaju twórczość językowa nie wiąże się z twórczością artystyczną, wypowiedziami o wyraźnym charakterze ironicznym itp., zwykle bywa postrzegana przez otoczenie nie tylko jako niedopuszczalny błąd językowy, ale również jako wskaźnik niedostatecznego wykształcenia, obycia lub niewystarczającej bazy kognitywnej, co skłania użytkowników do normatywnego posługiwania się zasobami leksykalnymi oraz regułami gramatycznymi.

Celem prezentacji materiału było przedstawienie pewnej systematyczności zachowań językowych dzieci, wynikających z potrzeb pragmatycznych. Przeprowadzona analiza pokazuje większy stopień konkretyzacji dziecięcego językowego obrazu świata, co wiąże się z faktem, iż abstrakcyjny sposób myślenia kształtuje się w miarę upływu czasu i rozwoju dziecka. Dziecięcy obraz świata odzwierciedla więc procesy asocjacyjne oparte na wiedzy kognitywnej stosownie do wieku użytkowników języka.

Warto odnotować, iż trudności słowotwórcze wieku dziecięcego pokrywają się częściowo z problemami, na które natrafiają osoby uczące się języka obcego, ponieważ zwykle dotyczą one wszelkich nieregularności o charakterze gramatycznym. Inne przypadki wiążą się z kolei z pragmatyką i mechanizmami kognitywnymi, zachodzącymi w naszym umyśle - jeśli nie znamy w języku obcym wyrazu oznaczającego dane pojęcie, staramy się, szczególnie w początkowej fazie nauki, tworzyć nazwy w oparciu o analogię, wykorzystując znajomość „działania" systemu językowego. Kiedy rozpoczynamy naukę języka obcego, jesteśmy trochę jak dzieci we mgle abstrakcyjnych reguł językowych, chociaż wyposażeni w o wiele większą wiedzę kognitywną.

\section{Bibliografia}

Grzegorczykowa R., Puzynina J. (1979), Stowotwórstwo współczesnego języka polskiego, Warszawa. Земская Е. А. (2007), Словообразование как деятельность, Москва.

Потебня А. А. (1976), Эстетика и поэтика, Москва.

Ратайчик К. (2010), Относительно детской контаминации (на материале русского языка), „Acta Universitatis Lodziensis”, Folia Linguistica Rossica 6, Łódź, s. 141-147.

Rozwadowski J. (1960), Wybór pism, t. III: Językoznawstwo ogólne, Warszawa.

Тухарели Н. Л. (2001), Детская языковая картина мира как предмет лингвистического изучения, [w:] В. В. Красных, А. И. Изотов (ред.), Язык. Сознание. Коммуникация, вып. 17, Москва, с. 5-10.

Тухарели Н. Л. (2002), Семантическая оппозиция маленький - большой в детской языковой картине мира, [в:] В. В. Красных, А. И. Изотов (ред.), Язык. Сознание. Коммуникация, вып. 12, Москва, с. 41-50.

Харченко В. К. (2002), Словарь современного детского языка, т. 1-2, Белгород.

Цейтлин С. Н. (2000), Язык и ребенок. Лингвистика детской речи, Москва.

Чуковский К. (2001), От двух до пяти, http://www.litmir.net/br/?b=72192\&p=3, 02.01.2014.

Ярцева В. Н. (ред.) (2002), Лингвистический энциклопедический словарь, Москва. 


\section{Jolanta Jóźwiak}

\section{Linguistic creativity of children (on material of Russian language)}

\section{Summary}

The aim of the paper is to present specific linguistic creations of children in Russian language. Two groups of lexems are discussed: structural modifications, which have potential character, and occasional linguistic innovations. Children use many unconventional derivative formants and root words instead of traditional ones, but their linguistic behaviour is based on associations, analogy and logic according to the cognitive knowledge on the given stage of their development. 